ROZ D Z I A E 14 .

\title{
AFRICAN SWINE FEVER I ZMIANY W PRODUKCJI WIEPRZOWEGO ŻYWCA RZEŹNEGO W PODLASKIEM ${ }^{1}$
}

\author{
Wojciech Florkowski ${ }^{2}$
}

\section{Wstęp}

Rolnictwo jest ważnym sektorem gospodarczym dla województwa podlaskiego i jego udział w regionalnym PKB był niemal trzykrotnie wyższy niż w PKB kraju w 2015 roku. Produkt Krajowy Brutto województwa podlaskiego wyniósł 39602 mln PLN w 2015 roku i wzrósł o około miliard w porównaniu do roku $2014^{3}$. Udział rolnictwa, leśnictwa, rybołówstwa i łowiectwa w PKB województwa spadł z 7,4\% w 2014 roku do 6,0\% w 2015 roku, odzwierciedlając spadek wartości z $2530 \mathrm{mln}$ zł do

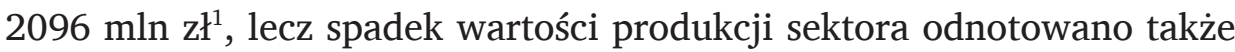
na poziomie kraju. Podlaskie jest jednym z trzech czołowych regionów produkcji mleka krowiego, głównie z uwagi na sprzyjające warunki naturalne w części regionu. Dla gospodarstw rolnych niespecjalizujących się w mleczarstwie, produkcja trzody chlewnej ma znaczenie ekonomiczne

${ }^{1}$ Od autora: temat niniejszego opracowania w zamierzeniu miał być rozwinięty w dużo szerszym projekcie badawczym, realizowanym z dr. hab. Adamem Sadowskim, profesorem UwB, w 2018 roku i Jego Pamięci to opracowanie poświęcam.

${ }^{2}$ Prof. Wojciech Florkowski, Ph.D., University of Georgia.

${ }^{3}$ Urząd Statystyczny w Białymstoku. Rocznik Statystyczny Województwa Podlaskiego, Białystok 2017. 
i dominują w niej gospodarstwa indywidualne. Udział gospodarstw rodzinnych w produkcji wieprzowego żywca rzeźnego pozostaje niemal niezmieniony na poziomie 98\% w okresie 1999-2017 (wykres 14.1.). Tego rodzaju profil produkcji trzody odbiega wyraźnie od tendencji ogólnokrajowej, gdzie udział gospodarstw rodzinnych systematycznie maleje i wyniósł 79\% w 2017 roku. Konsekwencje zakłócenia produkcji wieprzowego żywca rzeźnego są zatem znaczące dla gospodarstw rodzinnych i mogą oddziaływać na gospodarkę lokalną. Rozprzestrzeniająca się obecność ASF (African Swine Fever lub afrykański pomór świń) w Polsce zagraża produkcji trzody chlewnej szczególnie tam, gdzie ten rodzaj produkcji pozostaje ważnym źródłem dochodów z rolnictwa. Podlaskie, niemal niezmiennie, plasowało się na siódmym miejscu w wielkości produkcji żywca wieprzowego w latach 1999-20174.

Wykres 14.1. Odsetek gospodarstw indywidualnych produkujących trzodę chlewną, 1999-2017

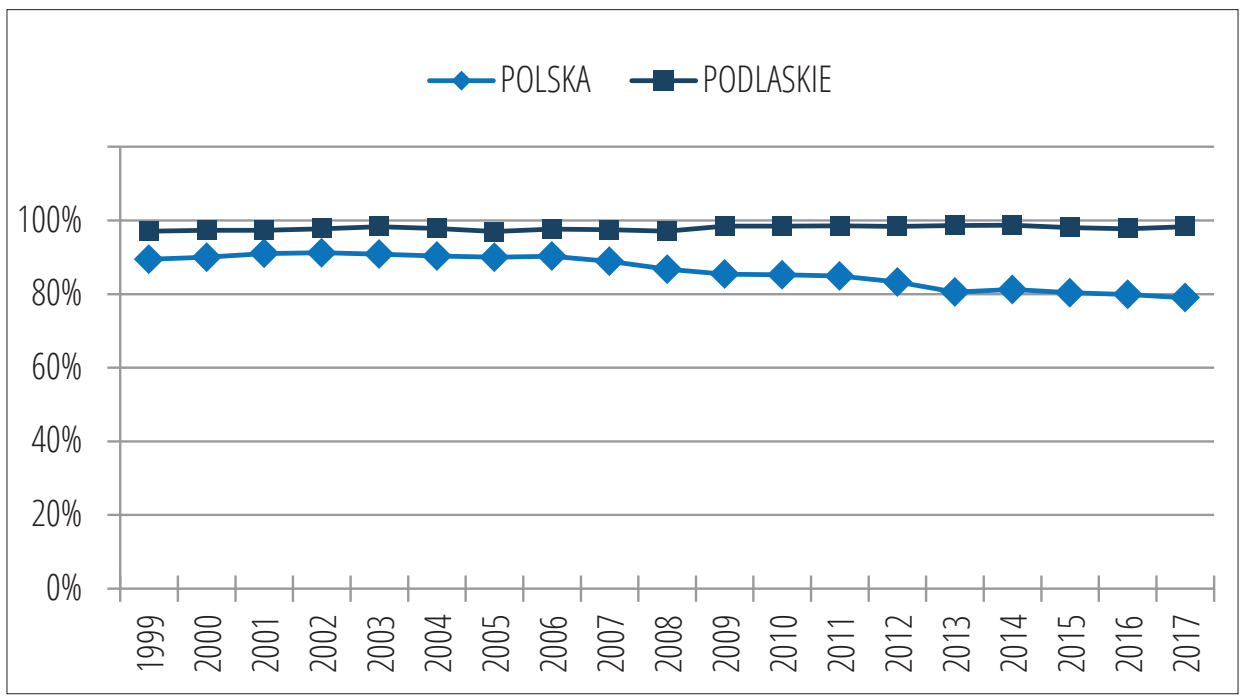

Źródło: opracowanie własne na podstawie: Bank Danych Lokalnych, 2019.

${ }^{4}$ Bank Danych Lokalnych. GUS, Warszawa. BDL 2019, https://bdl.stat.gov.pl/ BDL/start [data dostępu: 24.05.2019]. 
Od 2013 roku, tj. na rok przed oficjalnym potwierdzeniem pierwszego ogniska ASF w Polsce, liczba gospodarstw rodzinnych produkujących trzodę chlewną spadła w województwie podlaskim z 103,654 do 90,897 w 2017 roku, tj. o 12,3\%. W tym samym okresie, liczba gospodarstw wszystkich typów produkujących trzodę w Polsce wzrosła o 17,9\%. Odmienny kierunek zmian produkcji wieprzowego żywca rzeźnego w regionie i Polsce powiązać należy z zagrożeniem ASF, które mogło przyśpieszyć rezygnację części gospodarstw rodzinnych z produkcji trzody, tym bardziej, że pierwsze dwa ogniska ASF w kraju potwierdzono na Podlasiu w 2014 roku, a już w 2016 roku liczba przypadków ASF wyniosła 18 w Podlaskiem na 20 ognisk ogółem ${ }^{5}$.

Celem niniejszego rozdziału jest analiza zmian w sektorze produkcji wieprzowego żywca rzeźnego w województwie podlaskim ze szczególnym uwzględnieniem okresu od potwierdzenia przypadków ASF. Posługując się publicznie dostępnymi danymi i metodą opisową, podjęto próbę powiązania obserwowanych zmian z obecnością ASF i zwiększonym ryzykiem przy produkcji trzody. Wykorzystano także dostępną literaturę dotyczącą zagadnienia ASF i jego wpływu na sektor wieprzowiny w Polsce. Zaobserwowane zjawiska zilustrowano metodami graficznymi oraz miarami statystyki opisowej. Rezygnacja z produkcji trzody w wyniku zagrożenia ASF przez gospodarstwa rodzinne wywoła procesy dostosowawcze, których przebieg, z uwagi na brak danych o decyzjach gospodarstw, można tylko ogólnie naszkicować, a które mają potencjalnie duże znaczenie dla gospodarek poszczególnych gmin. Awersja rolników do ryzyka może spowodować wybijanie trzody w gospodarstwach, dla których ten rodzaj produkcji miał nieproporcjonalne do jej rozmiarów znaczenie ekonomiczne. Pozbawienie się tego źródła dochodu i niemożliwość znalezienia równie dochodowej gałęzi produkcji zagraża osłabieniem lokalnej gospodarki, a także zmniejszeniem wpływów do budżetu gminy. Dochody własne gminy decydują

\footnotetext{
${ }^{5}$ M. Tereszuk, Rynek mięsa wieprzowego $w$ Polsce $w$ obliczu afrykańskiego pomoru świń (ASF), „Problemy Rolnictwa Światowego” 2018, nr 18(4), s. 306-314.
} 
o możliwościach realizowania własnych projektów i skutecznemu ubieganiu się o dofinansowanie projektów z unijnych funduszy strukturalnych.

\subsection{African Swine Fever (ASF) lub afrykański pomór świń}

Afrykański pomór świń to choroba wirusowa dzików i świń nieszkodliwa dla człowieka lub innych gatunków zwierząt ${ }^{6}$. Choroba znana jest od prawie stu lat ${ }^{7}$. We Włoszech na Sardynii jest obecna od 1978 roku $^{8}$. Wskazuje się, że wirus obecny w Polsce pierwotnie trafił z Afryki do Gruzji w 2007 roku $^{9}$. Od początku jej stwierdzenia w UE (na Litwie) w 2014 roku, 95\% przypadków dotyczyło dzików ${ }^{10}$. Wirus ASF potrafi przeżyć do 8 miesięcy w środowisku, a w tkankach zamrożonych nawet dłużej. Do tej pory nie wynaleziono szczepionki przeciw tej chorobie. Pierwszy przypadek w Polsce odnotowano 1 lutego 2014 roku u padłego dzika w województwie podlaskim. Początkowo program bioasekuracji realizowano od kwietnia 2015 roku tylko w tym województwie po stwierdzeniu trzech przypadków ASF w stadach trzody chlewnej ${ }^{11}$. Choroba ta jest zwalczania z urzędu.

${ }^{6}$ S. Mroczkowski, ASF i nielegalny ubój - gorące tematy, „Przegląd Hodowlany” 2019, nr 2, s. 1-2.

${ }^{7}$ P.J. Sánchez-Cordón i in., African swine fever: A re-emerging viral disease threatening the global pig industry, "The Veterinary Journal" 2018, nr 233, s. 41-48.

${ }^{8} \mathrm{~S}$. Cappai i in., Evaluation of biological and socio-economic factors related to persistence of African swine fever in Sardinia, "Preventive Veterinary Medicine" 2018, nr 152, s. 1-11.

${ }^{9}$ R.S. Miller i in., Prospects for improving management of animal diseaseintroductions using disease-dynamic model, "Journal of Animal Science" 2019, nr 97, s. 2291-2307.

${ }^{10}$ I. Iglesias i in., New approach to modelling diseases: Temporal patterns of African Swine Fever in the European Union (2014-2017), "Journal of Animal Science" 2018, nr 96 (Supp 3), s. 517.

${ }^{11}$ NIK o programie bioasekuracji ASF - nieskuteczny, https://biznes.interia.pl/ gospodarka/news-nik-o-programie-bioasekuracji-asf-nieskuteczny,nId,4103057 [data dostępu: 12.07.2019]. 
Do niedawna uznawano ASF za problem krajów Europy Wschodniej (m.in. w Rosji, Ukraiie), później obecność wirusa stwierdzono w krajach nadbałtyckich, w tym na Litwie, z którą graniczy województwo podlaskie. W ciągu zaledwie kilku lat choroba rozprzestrzeniła się i potwierdzono jej obecność także w Czechach, Słowacji, i Rumunii ${ }^{12}$, a także dotarła do świń domowych w Bułgarii i dzików na Węgrzech ${ }^{13}$. Sugeruje się, że w latach 2014-2015 i 2016-2017 wirus ASF szerzył się o 1-2 km na miesiąc, choć tempo różniło się pomiędzy krajami.

Trudność w zwalczaniu ASF polega na tym, że jest wiele dróg zakażenia: przez paszę, ściółkę, pojazdy, żywe i martwe zwierzęta, a przede wszystkim dziki i człowieka. Wirusa rozprzestrzeniają także kleszcze. Niezbędne jest stosowanie zasad bioasekuracji, jak również ograniczenie populacji dzików. Odstrzał dzików jest skutecznym narzędziem kontroli ASF w opinii European Food Safety Agency (EFSA). Choroba ta stanowi poważne zagrożenie dla sektora wieprzowego żywca rzeźnego w UE.

\subsection{Produkcja żywca wieprzowego}

Zmiany w produkcji żywca wieprzowego w województwie podlaskim przebiegały podobnie do zmian w kraju w latach 2000-2013 (wykres 14.2.).

Dopiero od 2014 roku, kiedy zanotowano dwa ogniska ASF na Podlasiu, zmiany w produkcji wieprzowego żywca rzeźnego w Polsce i na Podlasiu wykazują odmienne tendencje. Wielkość zmian produkcji w Podlaskiem oscylowała i była ujemna w 2014 i 2016 roku, przy czym spadki procentowo były większe niż wzrost produkcji w latach 2015 i 2017. Średnie roczne tempo wzrostu produkcji za lata 2014-2017 w kraju wyniosło 4,3\%, natomiast w Podlaskiem średnie roczne tempo spadku wyniosło niemal 3\%.

12 Z. Pejsak, M. Truszczynski, Wnioski zwiąane z występowaniem ASF w państwach bałtyckich i Polsce, „Życie Weterynaryjne” 2018, nr 93(10), s. 683-685.

${ }^{13}$ EFSA, Epidemiological analyses of African swine fever in the Baltic States and Poland, "EFSA Journal" 2018, nr 16(11), s. 5494. 
Wykres 14.2. Dynamika zmian w produkcji żywca wieprzowego we wszystkich rodzajach gospodarstw w Podlaskiem i Polsce (rok poprzedni $=100$ )

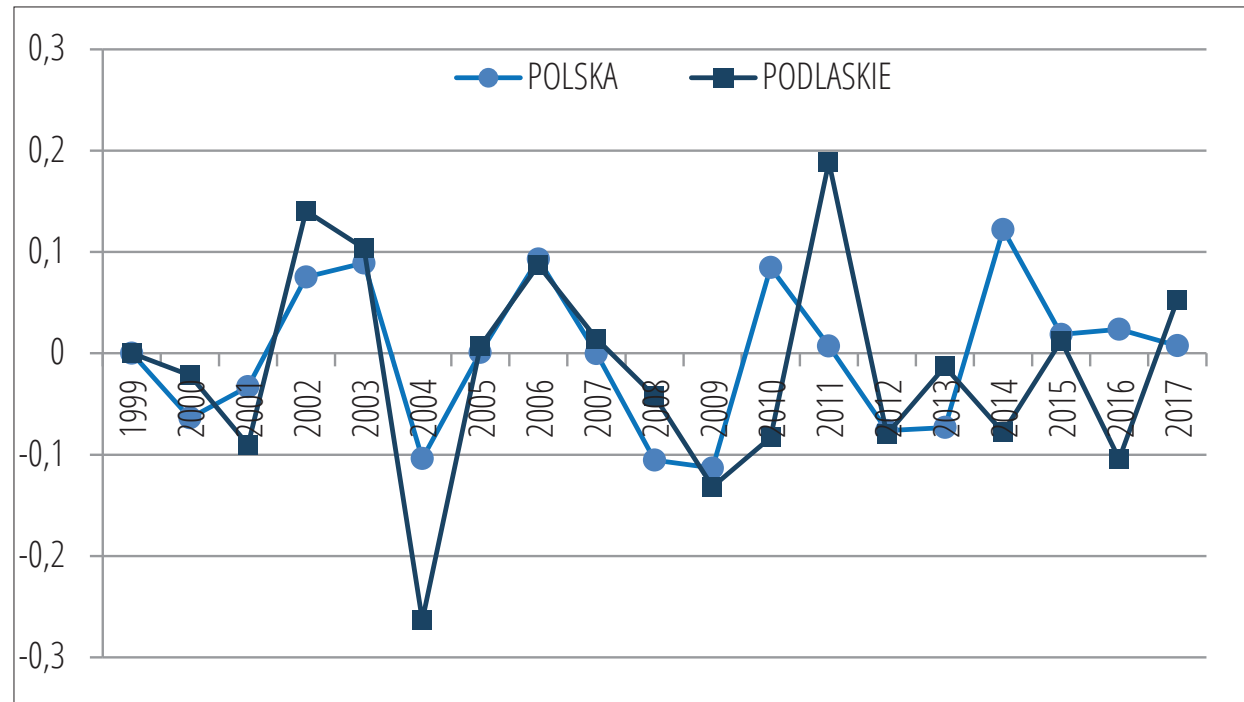

Źródło: opracowanie własne na podstawie: Bank Danych Lokalnych, 2019.

Współczynnik korelacji Pearsona dla tempa zmian w produkcji żywca wieprzowego między stopą wzrostu dla kraju a stopą dla Podlasia wynosi 0,654 przy poziomie istotności $\mathrm{p}=0,011$ za okres $1999-2013$. Stopy były pozytywnie i w miarę silnie skorelowane. Natomiast wyliczony współczynnik korelacji dla okresu 2014-2017 wskazuje na statystycznie znaczącą, negatywną korelację między stopami krajową i Podlasia. Wynosi on -0,537 przy poziomie istotności $\mathrm{p}=0,011$. Zmiana korelacji z pozytywnej na negatywną sugeruje, że spadek produkcji żywca wieprzowego na Podlasiu jest, przynajmniej w części, spowodowany pojawieniem się ognisk ASF i zwiększonym ryzykiem produkcji, które powoduje wycofanie się niektórych gospodarstw z produkcji trzody chlewnej.

Wydaje się, że inne regiony kraju skorzystały z pogarszających się warunków produkcji w województwie podlaskim i przyśpieszyły wzrost produkcji w swoich regionach. Produkcja w kraju zwiększyła się o około 117 tys. ton, podczas gdy w Podlaskiem spadła o 4421 ton między rokiem 2014 a 2017. Oznacza to, że 12757 gospodarstw, które zrezygnowały 
z produkcji żywca wieprzowego w regionie, zastąpił wzrost produkcji w gospodarstwach specjalizujących się w tego rodzaju produkcji. Zatem występowanie ASF powoduje zmiany w lokalizacji i skali produkcji trzody w regionie, jak i w kraju, ponieważ stopniowy wzrost wielkich gospodarstw specjalistycznych w innych województwach wpłynął na obserwowane zmiany w wielkości produkcji. Co więcej, produkcja na wielką skalę w cyklu zamkniętym może być narażona na mniejsze ryzyko infekcji zwierząt niż chów tradycyjny, nawet jeśli oba typy gospodarstw stosują metody bioasekuracji ${ }^{14}$. Jednakże ich stosowanie nie gwarantuje bezpieczeństwa produkcji w dużych gospodarstwach.

Porównanie trendów w produkcji wieprzowego żywca rzeźnego ogółem w województwem podlaskim i w Polsce wymagało użycia oddzielnych wykresów z uwagi na różnice w skali produkcji (wykresy 14.3. i 14.4.).

Wykres 14.3. Produkcja i trend produkcji wieprzowego żywca rzeźnego w Polsce

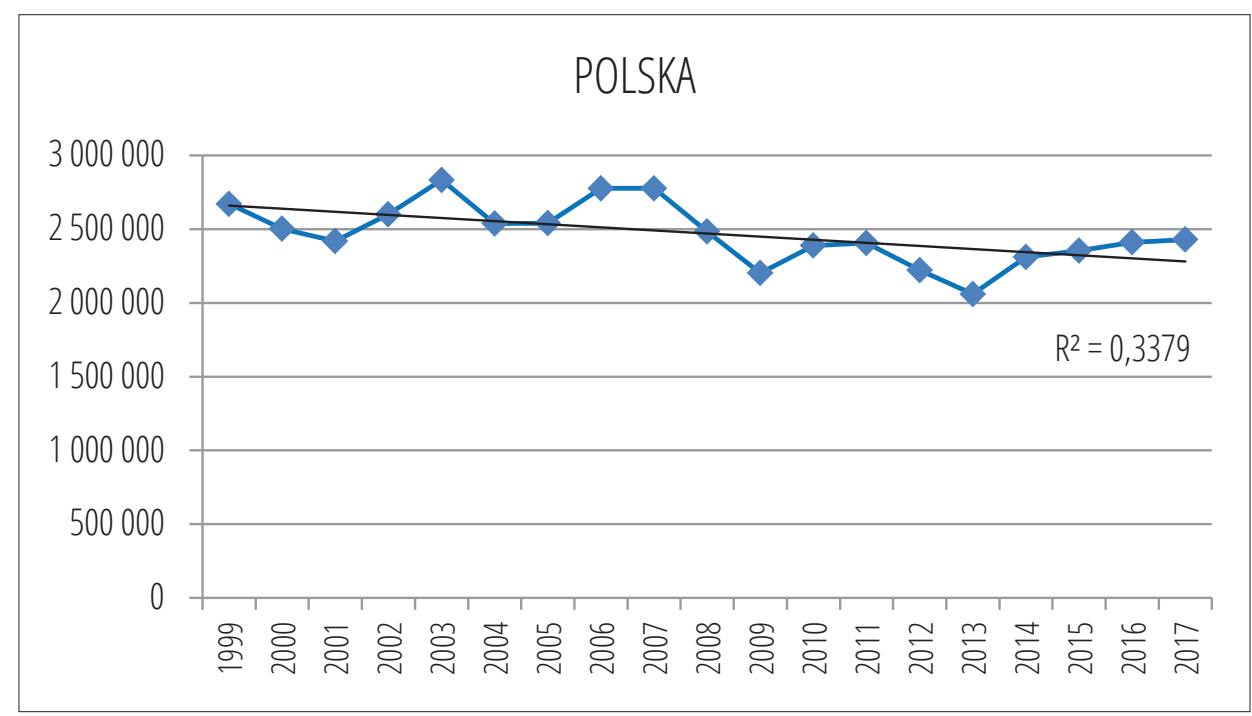

Źródło: opracowanie własne na podstawie: Bank Danych Lokalnych, 2019.

${ }^{14}$ D. Stancelewska, 10 najważniejszych zasad bioasekuracji, „Tygodnik Poradnik Rolniczy" 2017, https://www.tygodnik-rolniczy.pl/articles/hodowla-zwierzat/10-najwazniejszych-zasad-bioasekuracji [data dostępu: 12.07.2019]. 
Wykres 14.4. Produkcja i trend produkcji trzody chlewnej w województwie podlaskim

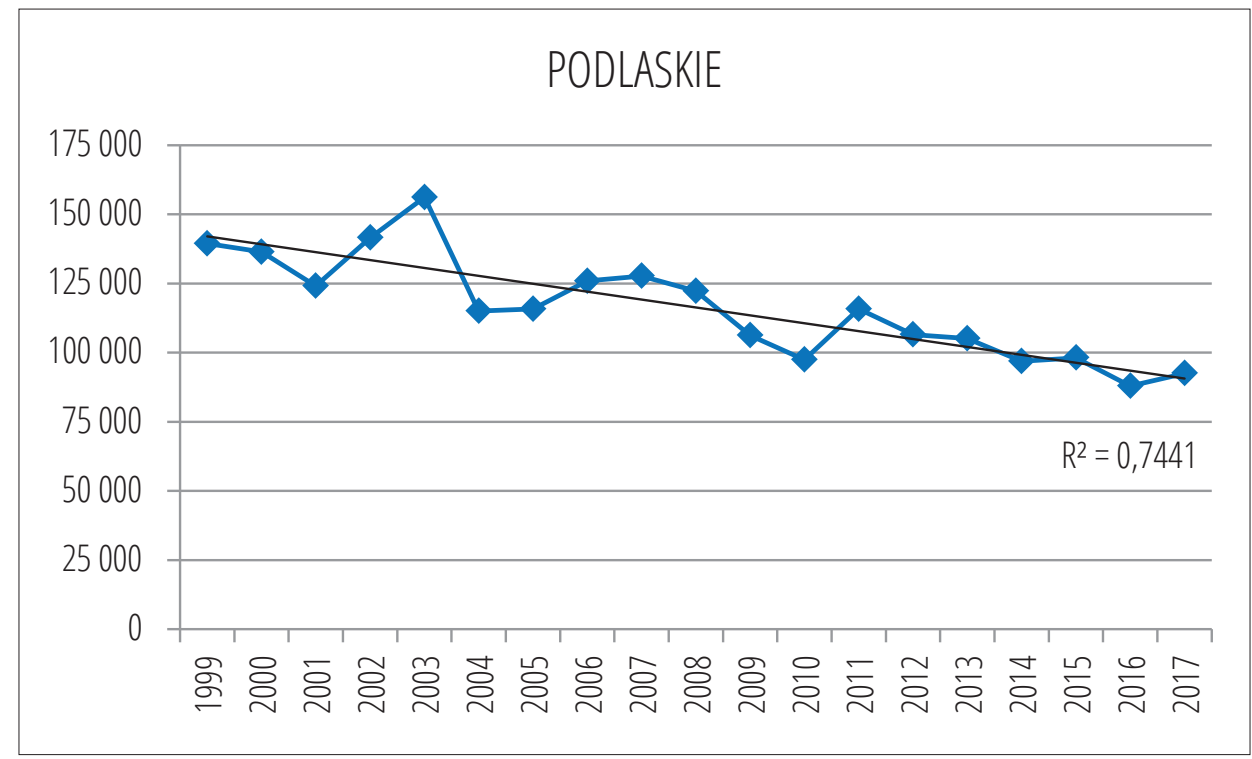

Źródło: opracowanie własne na podstawie: Bank Danych Lokalnych, 2019.

Zarówno w kraju, jak i na Podlasiu produkcja stopniowo spadała w badanym okresie, lecz jej tempo było znacznie wolniejsze w kraju niż w regionie. Od roku 2014, kiedy potwierdzono ogniska ASF, na Podlasiu przeważała tendencja spadkowa, podczas gdy w kraju notowano wzrost produkcji.

Wyliczony trend liniowy dla Polski, $y=-21039 x+3 E+06$, przy współczynniku determinacji $\mathrm{R}^{2}=0,3379$, objaśnia spadek produkcji w sposób umiarkowany (wykres 14.3.). Wartość współczynnika determinacji jest przeszło dwa razy większa dla trendu liniowego w przypadku zmian w produkcji żywca wieprzowego na Podlasiu. Wynosi on $\mathrm{R}^{2}=0,7441$, a wyliczony trend liniowy to $\mathrm{y}=-2854.9 \mathrm{x}+144899$ (wykres 14.4.).

Znamienny jest także spadek udziału żywca wieprzowego w produkcji żywca rzeźnego ogółem w latach 1999-2017. Ogólna tendencja spadkowa widoczna w skali kraju, jak i w województwie podlaskim nie była jednakowa dla obu obszarów (wykres 14.5.). 
Wykres 14.5. Udział żywca wieprzowego w produkcji żywca rzeźnego ogółem

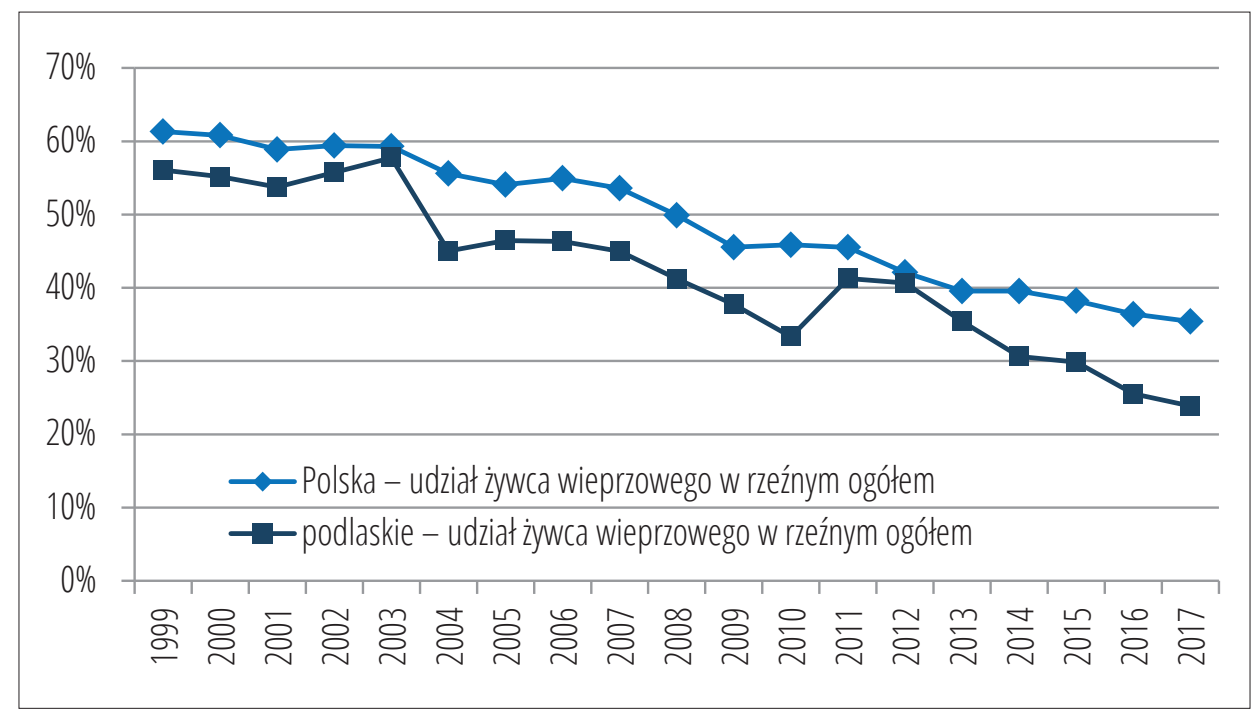

Źródło: opracowanie własne na podstawie: Bank Danych Lokalnych, 2019.

W Podlaskiem udział żywca wieprzowego był mniejszy niż w kraju ogółem w całym badanym okresie. Odzwierciedla to znaczenie produkcji mleka w regionie i związanej z tym produkcji żywca wołowego. Znaczenie żywca wołowego wynikało ze strategii wzrostu produkcji w gospodarstwach mlecznych przez zwiększanie stada krów na Podlasiu i mniejszą wówczas rolę zwiększania wydajności mlecznej od krowy ${ }^{15}$. Udział produkcji żywca wieprzowego wzrastał w latach bezpośrednio poprzedzających przystąpienie do Unii Europejskiej (UE), tj., w latach 2002-2003, i po części wynikał z oczekiwań producentów mleka, którzy wstrzymywali się z wymianą krów. Po przystąpieniu do UE, nastąpił kilkuletni spadek udziału żywca wieprzowego w produkcji żywca ogółem w regionie. Tylko w latach poprzedzających przystąpienie do UE i w okresie 2011-2013 udział żywca wieprzowego w produkcji żywca ogółem na Podlasiu był zbliżony do zmian w Polsce (wykres 14.5.). Od czasu stwierdzenia ognisk ASF w Podlaskiem

15 T. Sobczyński i in., Dairy farm cost efficiency in leading milk-producing regions in Poland, "Journal of Dairy Science" 2014, nr 98, s. 8294-8307. 
udział żywca wieprzowego wyraźnie zmalał powiększając różnice z obserwowanymi zmianami na poziomie kraju. Zatem, ponownie zjawisko spadku wiąże się z okresem pojawienia się ognisk ASF w 2014 roku i rezygnacją części gospodarstw z produkcji żywca wieprzowego.

\subsection{Afrykański pomór świń i co dalej?}

Rozprzestrzenianie się choroby w Polsce początkowo wiązało się z przenoszeniem wirusa przede wszystkim przez dziki. European Food Safety Agency zaleca sanitarny odstrzał dzików jako metodę zwalczania ASF. Podjęto decyzję o zwiększonym odstrzale dzików angażując Koła Łowieckie $^{16}$. W sezonie łowieckim 2017/2018 pozyskano niemal 340 tys. dzików, 20\% więcej niż w sezonie poprzednim. Odstrzał sanitarny dzików ma wynosić 0,5 dzika na kilometr kwadratowy w 2019 roku ${ }^{17}$.

W celu zmniejszenia ryzyka zakażeniem ASF, Główny Inspektorat Weterynaryjny wydał szczegółowe przepisy ${ }^{18}$. Wymagają one jak najszybszej likwidacji stada, w którym stwierdzono obecność ASF. Bezpośrednim skutkiem likwidacji jest zakłócenie produkcji żywca wieprzowego w gospodarstwie dotkniętym chorobą, a ponadto wszystkich innych gospodarstw produkujących żywiec wieprzowy w promieniu $3 \mathrm{~km}$. Oznacza to faktyczne objęcie szczególnymi przepisami wszystkich gospodarstw we wsi, a ponadto przepisy zawieszają wywóz żywca przez okres od 21 do 40 dni w zależności od warunków. Utrudnienia dotyczą szczególnie gospodarstw produkujących kilka sztuk żywca, gdzie zwierzęta karmione są paszą z własnych pól, i które sporadycznie sprzedają pojedyncze sztuki na ubój.

${ }^{16}$ Myśliwi zwalczają ASF, 2019, https://www.pzlow.pl/index.php/dla-mediow/23-mysliwi-zwalczaja-asf [data dostępu: 15.07.2019].

${ }^{17}$ Nowe ogniska ASF $w$ chlewniach. Wirus jest już na Mazowszu, 2019, https:// www.tygodnik-rolniczy.pl/articles/aktualnosci_nowe-ogniska-asf-w-chlewniach-wirus-jest-juz-na-mazowszu [data dostępu: 17.07.2019].

${ }^{18}$ Afrykański pomór świń (ASF), https://www.wetgiw.gov.pl/nadzor-weterynaryjny/afrykanski-pomor-swin [data dostępu: 01.10.2019]. 
Zakłócenie produkcji przekłada się na wyższe koszty produkcji, a także utrudnia zarządzanie finansami. W praktyce oznacza to potencjalne, uzależnione od wieku zwierząt, dłuższe niż oczekiwane żywienie zwierząt oraz opóźnienie ewentualnej sprzedaży. Opóźnienie sprzedaży zwierząt powoduje zmiany w przepływie gotówki naruszając płynność gospodarstwa. Co więcej, dłuższe skarmianie może wiązać się z pogorszeniem jakości tuszy i pogorszeniem przyrostów w zależności od wieku zwierząt oraz ryzykiem rynkowym wynikającym ze zmiany cen w odpowiedzi na dynamikę podaży i popytu. Niemożność wywiezienia zwierząt zagraża nie tylko cyklowi produkcyjnemu, lecz ekonomicznej żywotności gospodarstwa. Odszkodowanie wypłacane producentom ma efekt krótkoterminowy ${ }^{16}$, a rolnik staje w obliczu podjęcia decyzji dotyczącej przyszłości produkcji.

Przy braku zasobów finansowych, rolnicy mogą naruszać ograniczenia spowodowane wymogami bioasekuracji, w tym zawieszenia transportu zwierząt. Ponieważ monitorowanie każdego gospodarstwa jest trudne, rozprzestrzenianie choroby może wiązać się z naruszeniem reżimu bioasekuracji spowodowane położeniem ekonomicznym gospodarstwa. Informacje o nowych ogniskach ASF w województwie podlaskim nadal się pojawiają ${ }^{19}$. Dwa nowe ogniska potwierdzono w województwie warmińsko-mazurskim w 2019 roku $^{20}$. Ogółem liczba ognisk ASF od połowy lutego 2014 roku wyniosła $43^{15}$.

W czerwcu 2019 roku potwierdzono ogniska ASF w trzech gospodarstwach rolnych w województwie podlaskim, które razem posiadały na stanie 7 sztuk trzody chlewnej. Była to prawdopodobnie produkcja na samozaopatrzenie. Ponieważ produkcja żywności na samozaopatrzenie generalnie ulega gwałtownej redukcji w Polsce, liczba tego rodzaju gospodarstwa stale maleje. Samozaopatrzenie może wiązać się z ubóstwem

${ }^{19}$ ASF - nadciąga nowa fala? Wirus znów uderza $w$ chlewnie, tysiące wybitych świń, 2019, https://pomorska.pl/asf-nadciaga-nowa-fala-wirus-znow-uderza-w-chlewnie-tysiace-wybitych-swin/ar/c8-14185607 [data dostępu: 12.07.2019].

${ }^{20}$ B. Kociakowska, Kolejne stado świń ubite w zwiąku z ASF. To tzw. stado kontaktowe, 2019, https://pomorska.pl/kolejne-stado-swin-ubite-w-zwiazku-z-asf-to-tzw-stado-kontaktowe/ar/c8-14144843 [data dostępu: 12.07.2019]. 
właściciela, którego nie stać na stosowanie pełnej bioasekuracji. Wyeliminowanie produkcji wynikające z potrzeb materialnych jest trudne, a zagrożenie ASF nie ulega osłabieniu.

Najtrudniejszym czynnikiem w zwalczaniu ASF jest człowiek. Ilustracją roli czynnika ludzkiego jest niepowodzenie wyeliminowania ASF na Sardynii, które wiąże się z zachowaniem rolników, którzy podobnie jak w wielu gospodarstwach w Podlaskiem, hodują kilka sztuk trzody na potrzeby własnej rodziny. Niefrasobliwość i brak zrozumienia łatwości, z jaką przenosi się wirus, powodować może, że lokalnie dokonuje się transportu żywca podczas obowiązywania okresu kwarantanny w Polsce. Co więcej, poza motywami ekonomicznymi w naruszaniu reżimu bioasekuracji wsi, wskazuje się na motywy czysto ludzkie jako przyczynę powstawania ognisk $\mathrm{ASF}^{18}$. Działania celowe na szkodę innych są trudne do udokumentowania i skomplikowane poprzez różnorodność źródeł zakażenia, a walka z tego rodzaju zachowaniami wymaga nadzwyczajnej czujności.

Dla gospodarstw rodzinnych Podlasia produkujących żywiec wieprzowy zakażenie ASF i konieczność likwidacji stada może znacznie pogorszyć sytuację materialną, w tym poziom wyżywienia. Trzy przypadki ASF w trzech gospodarstwach w czerwcu 2019 roku służą jako tego przykład. Ogniska, w wyniku których zlikwidowano 7 sztuk świń, wykryto w gminie Trzcianne w powiecie monieckim oraz w gminach Mielnik i Siemiatycze $\mathrm{w}$ powiecie siemiatyckim. Wszystkie trzy gminy i oba powiaty posiadają znaczną liczbę gospodarstw domowych korzystających z różnych form pomocy społecznej. W powiecie monieckim 10,4\% mieszkańców otrzymuje pomoc, w tym 7\% sklasyfikowano jako poniżej kryterium dochodowego w 2017 roku. W gminie Trzcianne, udziały wynoszą odpowiednio 15\% i 9,3\% mieszkańców. W przypadku gminy Mielnik i gminy Siemiatycze w powiecie siemiatyckim, 6,7\% i 5,3\% mieszkańców sklasyfikowano jako poniżej kryterium dochodowego, a 14,7\% i 7,3\% mieszkańców korzystało z pomocy społecznej. Dla porównania, w województwie podlaskim 7,3\% mieszkańców korzystało z pomocy społecznej, a w Polsce udział ten wyniósł 5,7\% w 2017 roku. Udział mieszkańców poniżej kryterium dochodowego wyniósł odpowiednio 5\% i 3,6\% w tym samym roku w Podlaskiem 
i w kraju. Przykład ten sugeruje związek między liczbą mieszkańców korzystających z pomocy społecznej a potencjalnym znaczeniem ryzyka zakażeniem ASF. Likwidacja choćby paru sztuk żywca może mieć poważne znaczenie dla konkretnego gospodarstwa. To nieproporcjonalnie duże względem wielkości stada znaczenie może motywować właściciela do niepełnego przestrzegania bioasekuracji i przyczynianie się do przenoszenia wirusa szybciej, niż jeśli miałyby go przenosić np. dziki.

W skali kraju, konsekwencje wynikające z ryzyka zagrożeniem ASF nie są bez znaczenia. Polska jest zaangażowana w międzynarodowy obrót wieprzowiną. Tegoroczne wybuchy zakażenia ASF spowodowały, że importerzy polskiej wieprzowiny zażądali konkretnych działań ze strony polskiego rządu. Bez spełnienia wymogu zwiększenia liczby lekarzy weterynarii monitorujących zakłady produkujące wieprzowinę na rynek amerykański, mogą zostać wprowadzone restrykcje grożące eksportowi o wartości 631 milionów $\mathrm{PLN}^{21}$. W tym kontekście, ASF nie jest problemem regionalnym, ale krajowym, a obecność wirusa w kilku krajach UE zagraża produkcji żywca wieprzowego na niespotykaną dotąd skalę.

W dłuższym okresie być może zostanie wynaleziona szczepionka, która pozwoli skutecznie chronić stada żywca wieprzowego przed wirusem ASF. Dostępność szczepionki i jej stosowanie wiązać się będzie z kosztami, które trudno przewidzieć. Do tej pory próby laboratoryjne ze szczepionką okazały się nieskuteczne ${ }^{22}$ chociaż ostatnio poinformowano o postępie w badaniach ${ }^{23}$. Obecnie odpowiedzialność za kontrolę ASF spada na powiatowe inspektoraty weterynaryjne, których ograniczone

${ }^{21}$ USA domagają się dodatkowych kontroli polskiej wieprzowiny. Wyznaczyły Polsce termin, 2019, https://www.polsatnews.pl/wiadomosc/2019-04-17/usa-domagajasie-dodatkowych-kontroli-polskiej-wieprzowiny-wyznaczyly-polsce-termin [data dostępu: 23.07.2019].

22 Y. Revilla i in., African swine fever virus biology and vaccine approaches, "Advances in Virus Research" 2017, nr 100, s. 41-74.

${ }^{23}$ J. Sheik, Phibro announces African Swine Fever vaccine progress, "Farm Journals Pork" 2019, https://www.porkbusiness.com/article/phibro-announces-african-swine-fever-vaccine-progress [data dostępu: 19.07.2019]. 
zasoby mogą być niewspółmierne do skali zagrożenia. Zaangażowanie ośrodków doradztwa rolniczego w informowanie rolników o konieczności monitorowania zwierząt, stosowaniu najprostszych metod bioasekuracji i uświadamianiu szerszych skutków obecności ASF jest niezbędne szczególnie wśród drobnych producentów, którzy ponoszą najdotkliwsze konsekwencje. Walka z ASF wymaga zrozumienia, że poszkodowanymi będą nie tylko drobni producenci mieszkający na peryferiach UE, lecz gospodarstwa specjalistyczne, ubojnie, przetwórcy i ostatecznie konsumenci wieprzowiny, a także budżety gmin w wyniku potencjalnego spadku dochodów rolników.

\section{Podsumowanie}

Podlaskie było pierwszym regionem w kraju, gdzie zidentyfikowano ogniska ASF wśród świń utrzymywanych w gospodarstwach. Od 2014 roku ASF rozprzestrzenił się do innych regionów i skala zagrożenia produkcji żywca wieprzowego stale rośnie, pomimo stosowania metod bioasekuracji oraz sanitarnego odstrzału dzików. Stwierdzone ogniska ASF wskazują na niewspółmiernie ważną rolę gospodarstw, które utrzymują kilka sztuk trzody hodowanych głównie na własne potrzeby. Najnowsze ogniska w województwie podlaskim likwidowano właśnie w tego rodzaju gospodarstwach znajdujących się w gminach z dużym, w porównaniu do średniej krajowej i regionu, udziałem ludności niezamożnej, korzystającej z pomocy społecznej.

Znaczenie drobnych producentów trzody w regionie oznacza potencjalne trudności w motywowaniu takich gospodarstw w bezwzględnym przestrzeganiu bioasekuracji oraz poddaniu się przepisom w przypadku stwierdzenia ogniska ASF w okolicy. Wysiłki w celu zatrzymania rozprzestrzeniania się wirusa ASF oraz jego eliminacji ze środowiska wymagają koordynacji wysiłków służby weterynaryjnej, doradztwa rolniczego, samorządów lokalnych, środków przekazu, oraz lokalnych organizacji 
społecznych ${ }^{24} \mathrm{w}$ upowszechnienie informacji o ekonomicznych konsekwencjach choroby dla gospodarstw rodzinnych i lokalnych społeczności. Powszechne zaangażowanie, monitorowanie i stosowanie się do przepisów oraz zapobieganie przenoszeniu wirusa przez mieszkańców, pasze, środki transportu jest nakazem chwili. Pouczenie mieszkańców o związku między chorobą a kondycją finansową gminy jest niezbędne, aby pokazać, iż skutki odczuwają i odczuwać będą nie tylko producenci, ale całe lokalne społeczności.

\section{Podziękowanie}

Dziękuję dr Joannie Rakowskiej za pomoc w przedstawieniu graficznym danych oraz Amandzie Hollar za pomoc w przygotowaniu manuskryptu.

${ }^{24}$ Przykładowo, Kół Gospodyń Wiejskich. 